\title{
Do more cards and terminals guarantee higher efficiency? The case of European Union banking
}

\author{
Kristina Kocisova \\ Department of Banking and Investment, Faculty of Economics \\ Technical University of Kosice \\ Slovakia \\ kristina.kocisova@tuke.sk
}

\section{Beata Gavurova}

Department of Banking and Investment, Faculty of Economics

Technical University of Kosice

Slovakia

beata.gavurova@tuke.sk.

\section{Jakub Sopko}

Department of Banking and Investment, Faculty of Economics

Technical University of Kosice

Slovakia

jakub.sopko@tuke.sk.

Abstract. Dynamic development of payment cards' use has been observed during the recent years in all the European Union (EU) Member States, as evidenced by the growth of issued cards, ATM, EFTPOS terminals, and the number and value of payments made through them. The aim of this paper is to assess whether the increasing number of payment cards and terminals really result in higher efficiency. In this case, the efficiency has been measured by means of Data Envelopment Analysis (DEA) using the data of the 27 EU countries, in 2005 and in 2015, namely non-radial and non-oriented Super SBM model under the assumption of a variable return to scale. The principal reasons of changes in efficiencies between 2005 and 2015 have been analyzed by means of the Malmquist index. The results of DEA analysis confirm the assumption that if an increase in a number of devices is not supported by their direct use by clients, it will only have negative impact on the banking sector in a form of efficiency lost.

words: payment cards, ATM; EFTPOS terminal, efficiency, Data Envelopment Analysis, European Union banking.

JEL Classification: G14, G21 


\section{INTRODUCTION}

Assessing the efficiency of banks and banking sectors is under constant interest, and not only that of supervisory authorities, but also of banks' clients (Chochol'áková et al., 2015; Naiwen et al., 2018). Most studies dealing with the issue of efficiency primarily concentrate on the impact of financial liberalization on banks' efficiency (Badawi et al., 2017; Mikalauskiene et al., 2016; Andrieș, 2016; Nuhiu et al., 2017; Puriwat \& Tripopsakul, 2017; Tregenna, 2009). One aspect of financial liberalization is a greater openness of the banking sectors and increasing availability of funds (Miklaszewska \& Kil, 2016). One way to achieve higher availability of funds is implementation of new technologies. In recent years, the banking sector has recorded rapid development in technologies' application. As of today, clients demand more quality from payment services in terms of speed and reliability of the payment systems, something that results in higher requirements to technologies used by banks (Bhasin, 2016; Lazányi, 2017).

Payment cards represent a contemporary tool of cashless payment systems, which are commonly used to cover expenses and realize cash withdrawals. The majority of transactions with payment cards are mainly realized through a network of ATMS and EFTPOS terminals of individual banks. Literature in this regard provides two different views on the growing number of ATMs and EFTPOS terminals. According to Prager (1999), the increasing number of ATMs and EFTPOS terminals has a positive effect on banks' operations and their overall performance. A wider network of ATMs and EFTPOS terminals brings the positives for banks in the form of "network effect" and "scale effect". The "network effect" means that the number of clients using the services of ATMs and EFTPOS terminals increases with a wider network owned by the bank. Each new ATM and terminal offered by a bank enhances its activity and attracts new clients. According to the "scale effect", the cost of the bank on the transactions realized through the network of ATMs and terminals decreases with the increasing number of realized transactions. This is confirmed also by Salonder and Shepard (1995), who argue that the growing number of ATMs and terminals brings the savings for a bank in term of decreasing costs. On the other hand, wider network of ATMs and terminals brings also some negatives. One of them is that wider network of devices and their usage by clients reduce the level of product diversity offered by banks, and this may force clients change the bank without generating high costs. Matutes and Padilla (1994) described it as the "substitution effect". According to Belás and Gabčová (2016), in today's banking sector, which is characterized by increasing competition, efficient management and diversity of products, it represents a significant opportunity to improve the performance of commercial banks.

Therefore, it may be assumed that whether a bank achieves some benefits from the expanding network of ATMs and terminals or not depends on which effects will be dominant. If positive effects are dominanting, the bank could offer more favorable products, and thus, can get more clients and achieve higher profits. On the other hand, if negative effects are dominating, this will be reflected in a loss of clients as well as a loss of profit. More frequent use of payment cards brings the new sources of profit for the banks, but this also means higher expenses associated with investment in rapidly upgrading information technologies. Payment cards provide bank clients with the possibility of a quick access to their money, but on the other side, they are also subject to considerable risks. These contradictions between pros and cons associated with the use of payment cards have a considerable impact on the decisions of banks about adopting and implementing new technologies, and this trend can be observed in almost all countries all over the world. By implementing new technologies, banks can gain more competitive advantages at both domestic and foreign markets, and this may allow them carry out their activities more effectively.

The aim of this study is to examine whether wider networks of ATMs and EFTPOS terminals and a higher number of payment cards are really a guarantee of higher efficiency in the banking sectors of the EU countries. The investigation was done on the banks clients' use of payment cards and their efficiency in 
relation to the number of devices in their countries. The analysis has been carried out during the period with a significant positive development in the related technologies (2005 and 2015). The DEA method, namely, the models of super-efficiency, was used as it allows finding the main outliers. Another reason to use DEA is that there is a lack of studies describing the implementation of this methodology in evaluation of how efficient is the use of the implemented technologies in banking specifically. The identification of which of the European banking sectors were positively affected by the implementation of new technologies and by the use of payment cards was performed. To investigate the changes in the efficiencies of the EU banking sectors between the years 2005 and 2015 the Malmquist index is applied.

The paper is divided into three parts. In the first part, the relevant literature was reviewed. The second part describes the methodology and the data applied. The third part presents the practical application of the DEA method in assessing the relative efficiency of the EU banking sectors. The paper concludes with findings as well as suggestions for future research.

\section{LITERATURE REVIEW}

There exist many studies that try to analyze the efficiency of the banking sector (Casu \& Girardone, 2006; Grigorian \& Manole, 2006; Szczygieł et al. 2015). In recent years, it may be observed that the banks are trying to find the ways to increase the revenue from its operations in a view of the introduction of modern concepts into its structures (Svitálková, 2014; Sinicakova et al, 2017; Zuzeviciute et al., 2017). This is particularly clear with technological development and telecommunications (Belás et al. 2016). The rapid development of information technologies, as well as many applications in the banking sector, which help the bank make a progress and be competitive in the market may be observed (Korauš et al, 2016; Pioetrowska et al. 2017; Jantoń-Drozdowska \& Mikołajewicz-Woźniak, 2017). The concept of e-banking, e-smart applications, internet banking, ATMs and EFTPOS terminals where payment cards are used represents the new era.

The efficiency of the banking sector can be measured by many methods, while the Data Envelopment Analysis (DEA) is one of them (Yang, 2017). This method is very popular in last years, as it allows multiple inputs and multiple outputs in the analysis of relative efficiency within the data set and under the used variables.

Damar (2006) used the DEA method to estimate the contribution of ATM networks on the productive efficiency of selected Turkish banks. He used the DEA method to calculate technical efficiency and scale efficiency during 2000-2003. The author examines whether the bank obtains positive benefits of implementing ATMs. The results determine the factors that allow banks to increase the level of efficiency. The competitive environment in the cities and the geographical distribution of ATM concepts are important aspects in relation to the efficiency of banks.

Authors, Floros and Giordano (2008), shows how useful can be a number of ATMs for estimating and modeling an efficiency. They analyzed efficiency of the banking sector in Greece, using data from top 10 commercial banks. In the study, the DEA was applied, namely CCR, BCC model and models of super efficiency, under the conditions of constant and variable return to scale. The result of their work suggested that more efficient were larger banks, and also the banks with a higher number of ATMs are more efficient than those with a lower number of ATMs.

Monitoring the effectiveness and cost savings for the individual banks is in many cases limited due to imperfect data or unavailability of data. Information on investments in IT (ATM) and economies of scale are in many cases the internal affairs of the bank. This restriction also confirmed Ou et al. (2009), who investigated the effect of ATM on the effectiveness of selected banks in Taiwan. The authors also concluded 
that IT investments in the banking sector have a positive impact on the efficiency of banks (discussion about efficiency problems is presented by Michalski (2014, 2016).

Filipovski and Flood (2010) analyzed the impact of the reforms introduced by the Australian Reserve Bank that influenced the concept of ATMs. The authors point to the effective implementation of changes in the charges. The reform resulted in an increase of the ATMs' numbers, and to increase the competitiveness of the banks. Flood, Hancock and Smith (2011) confirmed previous findings and they are claiming that the preferred deployment of ATMs has an impact on efficiency in managing cost-site banks.

The ATM was involved as an input variable in the DEA analysis in the paper presented by Kheng and Wooi (2011). They analyzed local banks in Malaysia during the period of 2003 and 2008. The analysis points to the sufficient supply of ATMs and lack of technical efficiency of foreign banks.

Adewoye and Omoregie (2013) analyzed the effect of the intensity of ATMs deployment on the cost efficiency in the condition of the Nigerian banking sector. In the second part of their analysis, they tried to identify the indicator influencing the level of ATMs deployment. As the variables, they used the size of banks, bank profitability, salary level, number of banks and value of transactions made via ATMs. They found out that the ATMs' deployment had a positive effect on cost efficiency. The decision of banks to implement new technologies was positively influenced by bank size, and value of ATM's transactions.

As can be seen in the world literature, there exist some studies trying to identify the impact of ATM network on bank efficiency. However, there also exists the gap within the realized studies, which should analyze if the implemented technologies were used by bank clients in a maximum possible way. Therefore, a wider network of terminals was analyzed together with a higher number of payment cards issued by banks, which were transformed effectively, and were used by banks' clients in a maximum possible way. The DEA method, namely super efficiency model, as it allows finding the main outliers. The Malmquist index was applied.to investigate the changes in the efficiencies of the European Union banking sectors in the years 2005 and 2015.

\section{METHODOLOGY}

The DEA is one of the methods for measuring relative efficiency of production units (DMU), which use the same multiple inputs to produce the same multiple outputs. The DEA is used to set up the best practice set of production units and to identify which units are inefficient compared to best practice set as well as to show the significance of the inefficiencies present. The basic DEA models, input or output oriented, allow calculating with a constant or variable return to the scale. The model using the assumption of a constant return to the scale is called CCR (Charnes, Cooper and Rhodes) model. The assumption of a constant return to scale can be accepted only if the production units operate under their optimal size, which is usually not possible. Therefore, the DEA model was upgraded into the BCC model (Banker, Charnes, Cooper) in order to calculate variable returns to scale.

Basic DEA models suffer from tied ranks, because the efficient units in a sample shared the same score of one. This problem can be removed by solving, so-called super efficiency model. Through this model, the researcher is able to distinguish among the efficient units in the sample and rank them.

In this study, $n$ banking sectors are considered $\left(D M U_{j}, j=1,2, \ldots, n\right)$, each consumes $m$ different inputs $\left(x_{i j}, i=1,2, \ldots, m\right)$ to produce $\mathrm{s}$ different outputs $\left(y_{r j}, r=1,2, \ldots, s\right)$. The matrix of inputs is marked $X=\left\{x_{i j}\right.$, $i=1,2, \ldots, m ; j=1,2, \ldots, n\}$ and the matrix of outputs $Y=\left\{y_{r j}, r=1,2, \ldots, s ; j=1,2, \ldots, n\right\}$. The assumption of a variable to scale combined with a non-radial and non-oriented Super SBM model in evaluating banking sectors in European Union countries in 2005 and in 2015 was used. The non-oriented aspect of SMB model removes the need to specify an orientation and captures the desire to improve both the inputs and outputs 
simultaneously. The non-radial aspect of the model captures that the movements on efficiency frontier will be not only radial, which able to calculate the efficiency in the Pareto-Koopmans sense.

The discussion about the super efficiency is taken under the assumption that the production unit DMU is SBM-efficient, i.e. it is strongly efficient under the SBM model. Based on the theory presented by Cooper, Seiford, and Tone (2007) the super efficiency model under the assumption of a variable return to scale can be defined as the optimal objective function value $\delta^{*}$ from the following program:

Subject to

$$
\delta^{*}=\min _{\bar{x}, \bar{y}, \lambda} \frac{\frac{1}{m} \sum_{i=1}^{m} \frac{\overline{x_{i}}}{\frac{x_{i o}}{s}}}{\frac{1}{s} \sum_{r=1}^{s} \frac{\overline{y_{r}}}{y_{r o}}}
$$

$$
\begin{gathered}
\bar{x} \geq \sum_{j=1, \neq o}^{n} \lambda_{j} x_{j} \\
\bar{y} \leq \sum_{j=1, \neq o}^{n} \lambda_{j} y_{j} \\
\sum_{j=1}^{n} \lambda_{j}=1, \quad \lambda_{j} \geq 0, \quad \forall j \\
\bar{x} \geq x_{o} \quad \text { and } \quad \bar{y} \leq y_{o} \\
\bar{y} \geq 0, \quad \lambda \geq 0
\end{gathered}
$$

The super efficiency score $\delta^{*}$ is not restricted to the interval $[0,1]$. Its value is always non-negative and for Super SBM technically efficient units are not smaller than 1 . There are two interpretations of this super efficiency score. The higher means the higher technical efficiency of the analyzing unit. It can alternatively be used for finding outliers in the dataset under analysis. Large values of super efficiency that seem out of the other series values indicate that the analyzed unit should be treated without a doubt as an outlier. (Zimková, 2015)

After the identification of outliers within the data set, the factors of efficiency change over time were examined. Similarly as Bod'a and Zimková (2016) as the main instrument that serves to this purpose will be used standard Malmquist index (presented by Malmquist (1953)) and its decomposition into the driving forces of productivity change. The Malmquist index that is based on the non-radial and non-oriented SBM model was used. This index is traditionally applied to measure productivity change between two time periods of a balanced panel of production units. It is defined as the product of catch-up effect and frontier-shift effect. Cooper, Seiford, and Tone (2007) defined that the catch-up (or recovery) effect relates to the degree to which a production unit improves or worsens its efficiency, while the frontier-shift (or innovation) effect reflects the change in the efficiency frontiers between the two time periods. The catch-up effect from the period 1 to period 2 can be measured by the following formula:

$$
\text { Catch }- \text { up }=\frac{\text { Efficiencyof }\left(x_{o}, y_{o}\right) \text { in period } 2 \text { with respect to period } 2 \text { frontie }}{\text { Efficiencyof }\left(x_{o}, y_{o}\right) \text { in period } 1 \text { with respect to period } 1 \text { frontie }}
$$


If the value of catch-up effect is higher than one, it can be interpreted as progress in relative efficiency from period 1 to period 2. The value of catch-up effect equal to one indicates no change, and the value lower than one indicates regress in relative efficiency from period 1 to period 2.

In addition to catch-up effect, we must take account of the frontier-shift effect in order to fully evaluate the productivity change since the catch-up effect is determined by the efficiencies being measured by the distances from the respective frontiers. The frontier-shift is defined as follow:

$$
\text { Frontier }- \text { shift }=\sqrt{\phi_{1} \phi_{2}}
$$

Where $\phi_{1}$ and $\phi_{2}$ are defined by following formulas:

$$
\begin{aligned}
\phi_{1} & =\frac{\text { Efficiencyof }\left(x_{o}, y_{o}\right) \text { in period } 1 \text { with respectto period } 1 \text { frontier }}{\text { Efficiencyof }\left(x_{o}, y_{o}\right) \text { in period } 1 \text { with respect to period } 2 \text { frontier }} \\
\phi_{2} & =\frac{\text { Efficiencyof }\left(x_{o}, y_{o}\right) \text { in period } 2 \text { with respect to period } 1 \text { frontier }}{\text { Efficiencyof }\left(x_{o}, y_{o}\right) \text { in period } 2 \text { with respect to period } 2 \text { frontier }}
\end{aligned}
$$

Frontier-shift higher than one indicates progress in the frontier technology around the evaluated production unit DMU from period 1 to period 2, while frontier-shift equal to one and frontier-shift lower than one indicate the status quo and regress in the frontier technology.

The Malmquist index is computed as the product of catch-up effect and frontier-shift effect using the following form:

$$
\text { Malmquist index }=(\text { Catch }- \text { up }) \cdot(\text { Frontier }- \text { shift })
$$

The Malmquist index higher than one indicates progress in the total factor productivity change of the evaluated production unit DMU, from period 1 to period 2. The Malmquist index equal to one indicates the status quo, and the Malmquist index lower than one indicates deterioration in the total factor productivity.

Firstly, the structure of used inputs and produced outputs in the banking sectors needs to be defined in order to assess if the banks' clients use payment cards effectively in relation to the number of devices that can use in their countries. Therefore, as the input variables were used a number of issued payment cards, a number of ATM, and a number of EFTPOS terminals in selected countries. As the output variables were considered number and value of payments realized through the payment cards. To eliminate the impact of the size of banking sectors, recalculation of each variable was performed in relation to a total number of employees in credit institutions in individual countries. As the main data source will be used database Statistical Data Warehouse, namely Payment and settlement systems statistics, published on the web page of European Central bank. The annual data in 2005 and in 2015 on the country level (27 European Union countries) are used.

\section{EMPIRICAL RESULTS AND DISCUSSION}

The methodology defined above was used to investigate whether a wider network of ATMs and EFTPOS terminals and a higher number of issued payment cards were a guarantee of higher efficiency in the EU banking sectors. The investigation focused on the fact if the banks' clients use payment cards 
effectively in relation to the number of devices that can use in their countries. The analysis is done during the period in which the mentioned technologies experienced a significant positive development.

The payment cards experienced a very dynamic development in last years, a significant increase can be seen in the number of payment card holders, but also in the number of places where the clients of banks can pay by cards through EFTPOS terminals or withdraw cash from ATMs. Figure 1 displays the development of payment cards issued by resident payment system participants in relation to a number of employees in credit institutions (CI) in analyzed countries. As can be seen in all analyzed countries the number of issued cards increased. The most dynamic development can be seen in the case of Finland, Ireland, Luxembourg and Denmark, where the share of issued payment cards per one employee increased more than $100 \%$. Only in a case of France, there can be observed a slow decrease in the number of issued payment cards between selected years (6.75\%). In average in all analyzed countries, the number of issued payment cards per one employee in credit institution increased by $46.12 \%$.

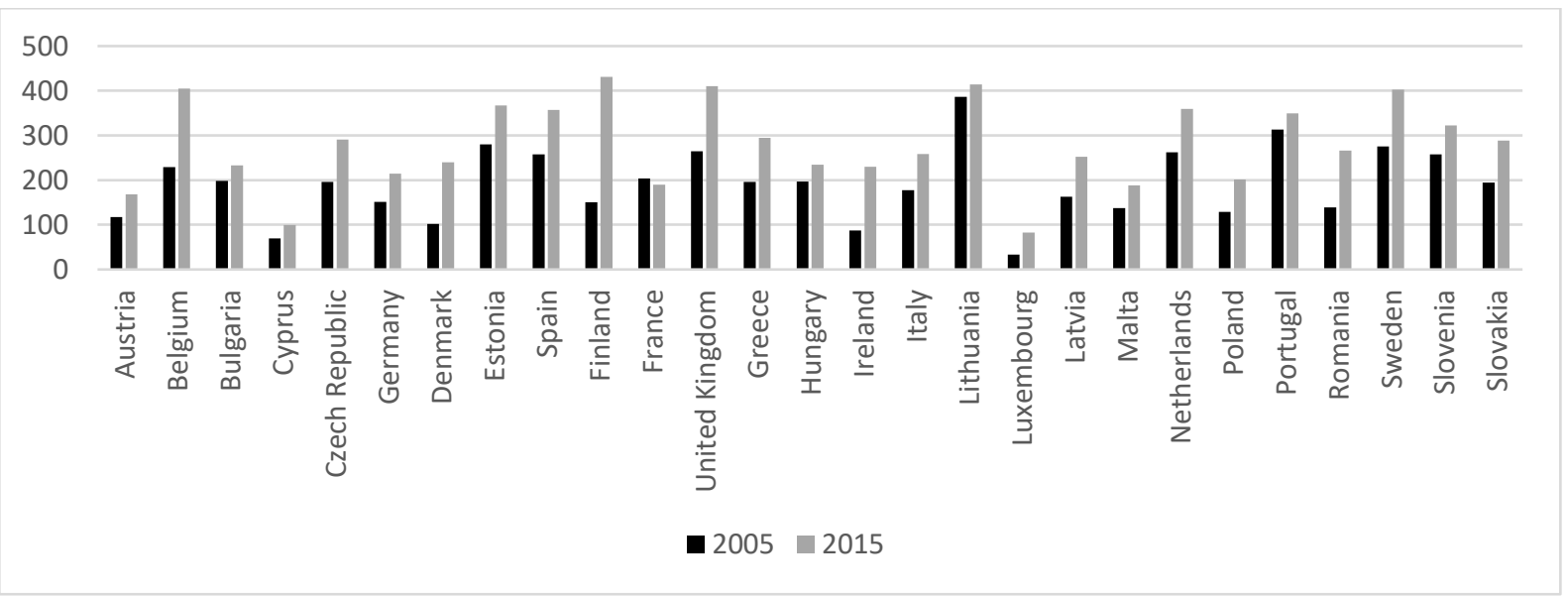

Figure 1. Number of issued payment cards per one employee in CI in EU countries Source: Prepared by authors

As the second input variable in the DEA model was used the number of ATMs in relation to a number of employees in credit institutions in analyzed countries. The development of this variable can be seen in Figure 2. The most dynamic development can be seen in the case of Poland and Romania, where the share of ATMs per one of employee increased more than 100\%. In the case of Denmark, Finland and Sweden there can be seen a slow decrease in the number of ATMs between selected years. In average in all analyzed countries, the number of ATMs per one employee in credit institution increased by $32.22 \%$. Withdrawing cash from an ATM is very popular and often use way of using payment cards in all European Union countries. In high developed countries the ATM networks have been built for a long time, so the intensity of the introduction of new equipment in last ten years was stagnating. On the other hand, in emerging countries, that have joined the European Union only in last years, we can see a sharp increase in these devices. The situation is the same also in the case of EFTPOS terminals.

Another way how the payment cards could be used by clients is for the realization of non-cash payments through the EFTPOS terminals. Therefore as the third input variable used in DEA model was the number of EFTPOS terminals per one employee in credit institutions in analyzed countries. The development of the implementation of these devices in various countries is shown in Figure 3. Also in a case of this variable, a rapid development can be observed. The fastest development can be seen in the case of Luxembourg, where the share of EFTPOS terminals per one of employee increased more than $1000 \%$. 
The rapid development higher than 300\% is monitored also in Bulgaria and Romania. In France and Sweden, there can be seen a slow decrease in the number of EFTPOS terminals between selected years. In average in all analyzed countries, the number of EFTPOS terminals per one employee in credit institution increased by $95.97 \%$.

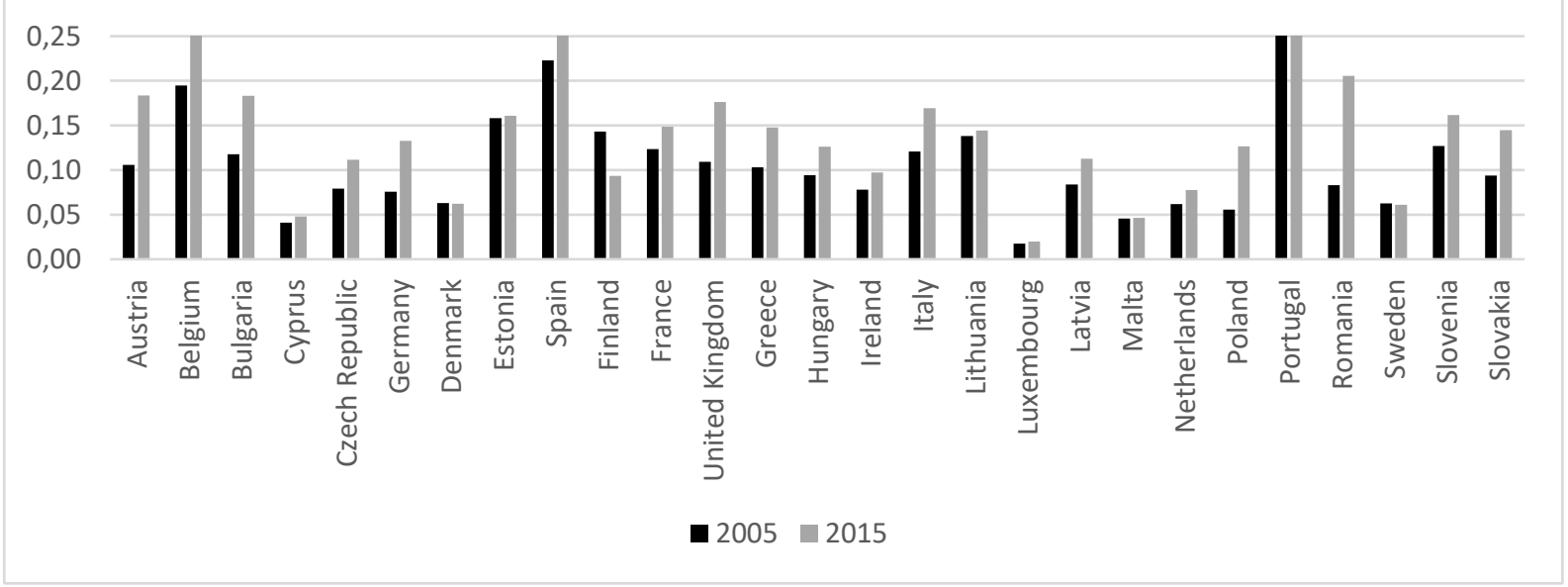

Figure 2. Number of ATMs per one employee in CI in EU countries Source: Prepared by authors

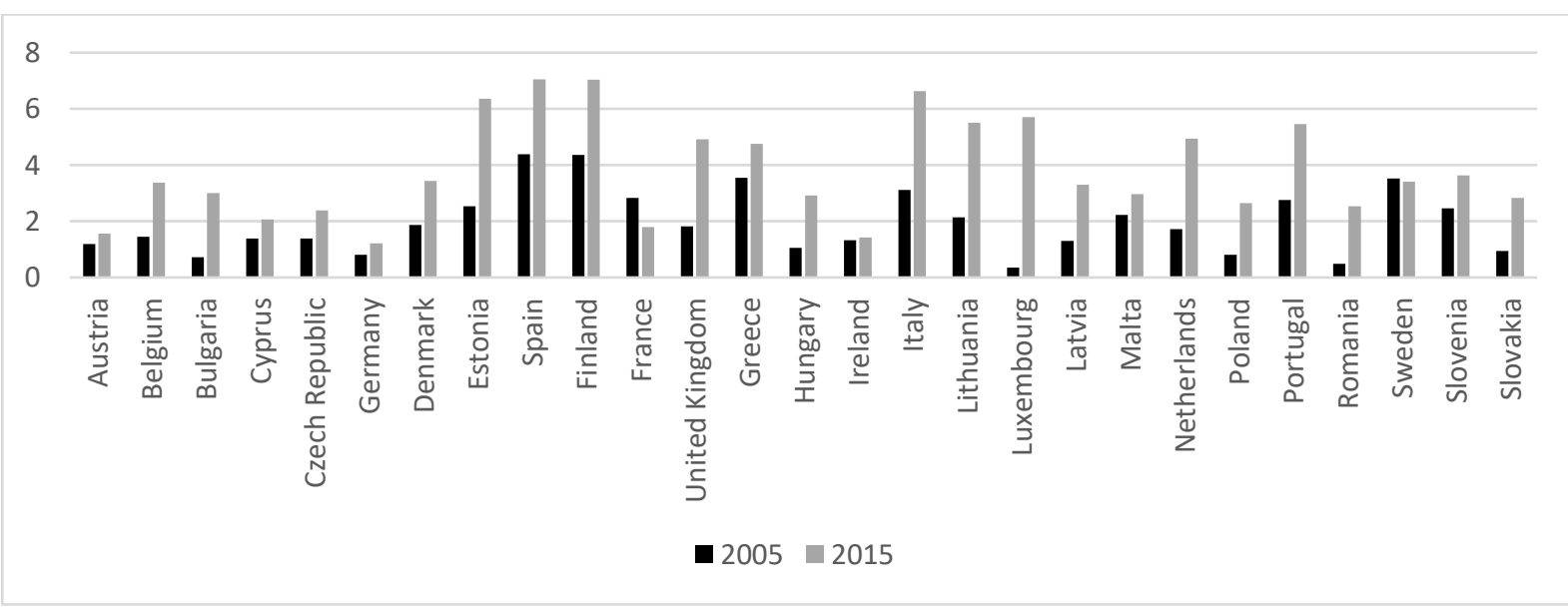

Figure 3. Number of EFTPOS terminals per one employee in CI in the EU countries Source: Prepared by authors

All these devices are offered by banks. The paper investigates if the implemented technologies were used by bank clients in a maximal possible way. As the indicators of successful usage of implemented devices were selected the number and the value of transactions realized by payment cards particular through ATMs and EFTPOS terminals. With the fast growth in the number of terminals and cards, the number and the value of payments realized through them also increased as is evident in Figure 4 and Figure 5.

The largest increase in the value of transactions realized via payment cards per one employee in credit institutions was found in Slovakia, where the value increased by more than 1000\% (Figure 4). The number of issued payment cards increased by $48.25 \%$, the number of ATMs increased by $54.33 \%$, and the number of EFTPOS terminals increased by $201 \%$ in comparison to a number of implemented technologies. In all cases, the growth was faster than the average of analyzed countries. In most of the analyzed countries, the 
growth rate in the value of transactions realized via payment cards reached a value greater than $100 \%$. Only in a case of Cyprus, Germany, Finland, France, Greece, Sweden and Slovenia the growth rates were slower.

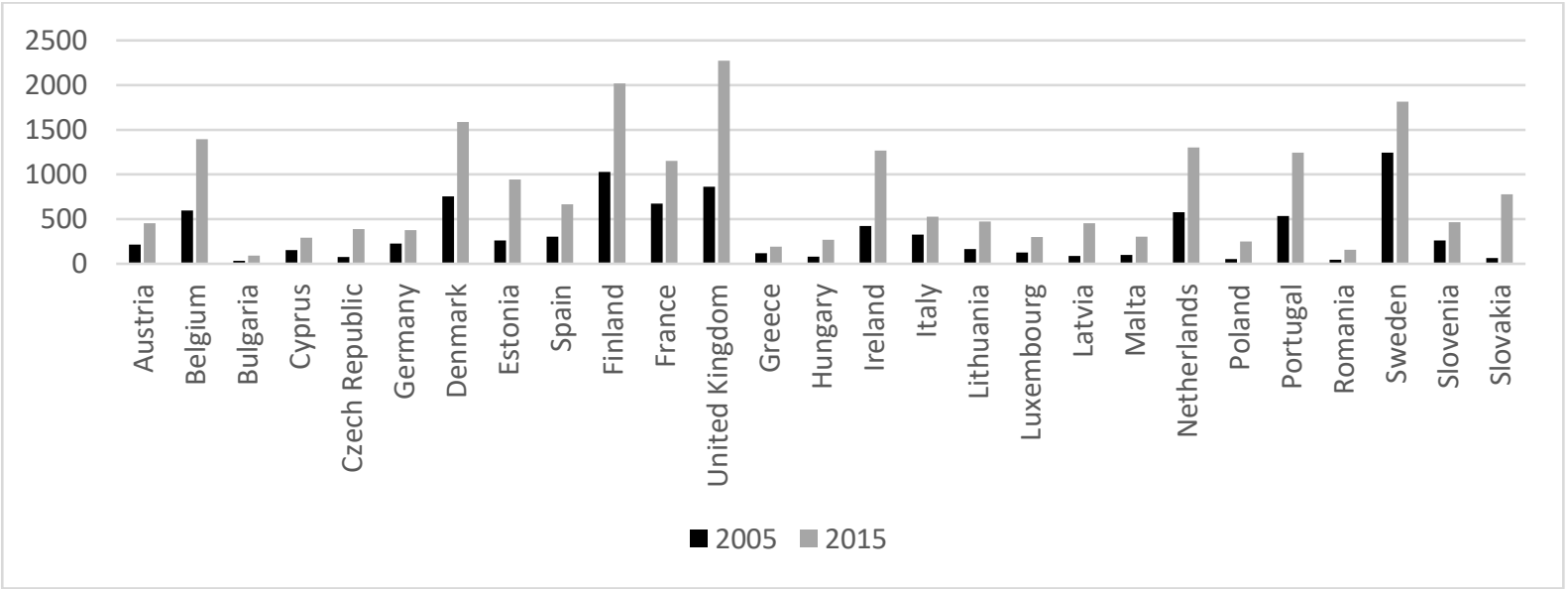

Figure 4. Value of transactions realized by payment cards per one employee in CI in the EU countries (thousands of EUR)

Source: Prepared by authors

The number of transactions realized via payment cards (Figure 5) shows that the Slovakia also reached the highest growth rate in the number of transactions realized via payment cards per one employee in credit institutions (816.38\%). The growth rate higher than 500\% can be found in the Czech Republic and Romania. On the other hand, an increase under the $100 \%$ is evident only in a case of four countries: Germany, France, Portugal and Slovenia.

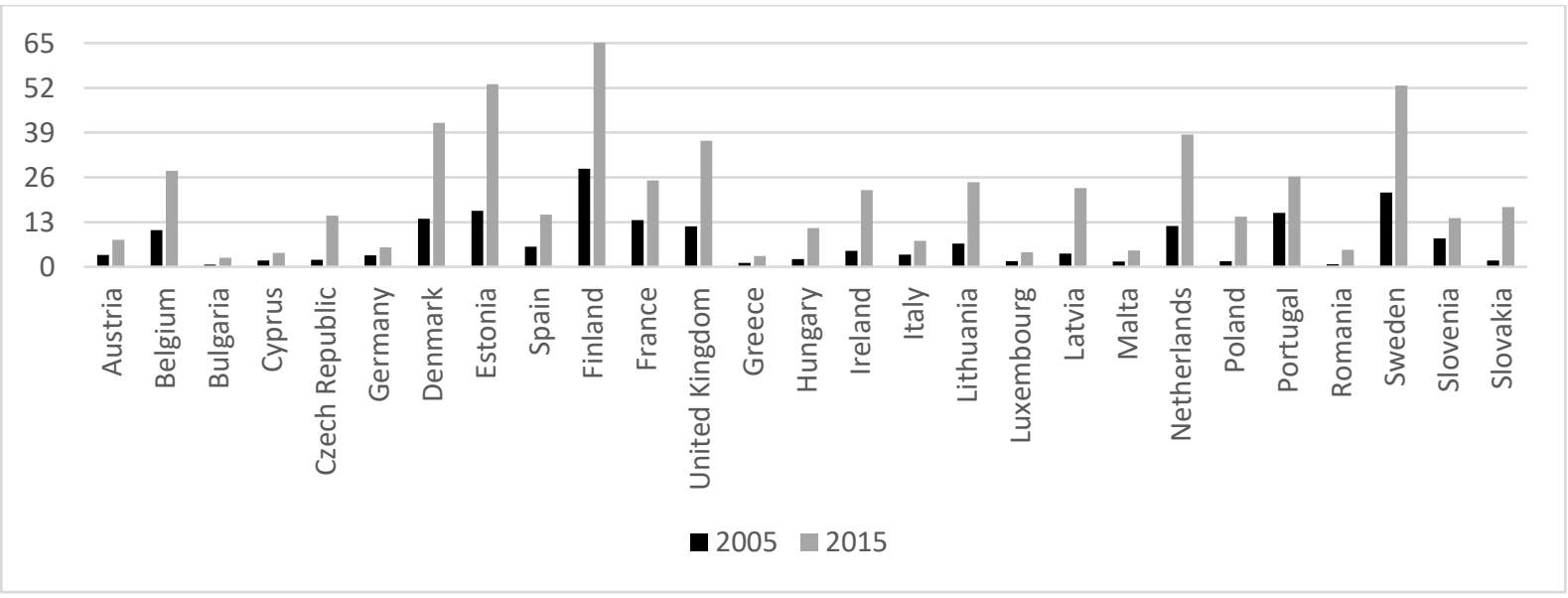

Figure 5. Number of transactions realized by payment cards per one employee in CI in the EU countries (thousands of EUR)

Source: Prepared by authors

The second part of the paper focuses on which banking sectors were positively affected by the implementation of new technologies and by the use of payment cards in 2005 and in 2015. According to an assumption, this positive impact should be transformed into the higher efficiency score estimated via the DEA model. The efficiency in this study was estimated using the computer program "DEA Solver-Pro software". The efficiencies were calculated using the non-radial and non-oriented Super SBM model. 
One of the advantages of super efficiency model is, that it allows identifying the outliers. The easiest way of how to identify them is through the box-plot analysis. In the next figure (Figure 6), the box-plot of super efficiency scores for both periods under consideration (2005 and 2015).

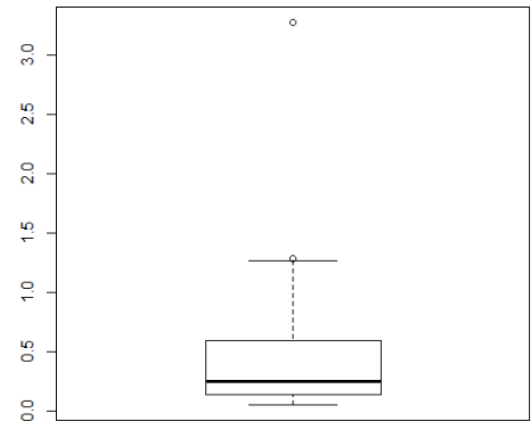

2005

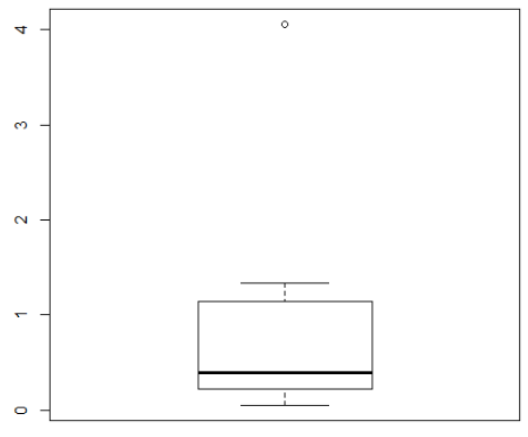

2015

Figure 6. Box-plot of super efficiency in the EU countries in 2005 and 2015 Source: Prepared by authors

As can be seen in the both years, the super efficiencies were skewed towards lower values, which reflected by moving the median values down. According to box-plot analysis, two outliers can be seen in 2005, and one in 2015. As the outliers in 2005 have been identified the banking sectors in Luxembourg and in Finland and in 2015 the banking sector in Ireland. The results of the super efficiency after identification of outliers for both periods under consideration (2005 and 2015) are presented in Table 1.

Calculation of the super efficiency points to the fact that most of the analyzed countries were positively influenced by the use of credit cards. According to the results of our analysis, the countries could be divided into three main groups:

- Within the first group, there are countries which in 2015 achieved higher efficiency and also better position in the ranking compared to 2005. In these countries, the percentage increase in the value and number of transactions realized by payment cards per one employee exceeded the percentage increase in the number of issued cards, ATMs and terminals, which resulted in the growth of efficiency. Within this group can be seen banking sectors in Austria, Cyprus, Czech Republic, Denmark, Estonia, France, Greece, Ireland, Latvia, Malta, Poland and Slovakia.

- The second group is characterized by an increase in efficiency score, but this increase wasn't reflected in strengthening position in the ranking. In this group can be seen Germany, Spain, United Kingdom, Hungary and Lithuania. Also in these countries, the percentage increase in the value and number of transactions realized by payment cards per one employee exceeded the percentage increase in the number of issued cards, ATMs and terminals, which resulted in the growth of efficiency.

- The last group is created by countries, where the efficiency decreased. In these countries, the growth rate of one of the input variables (the number of issued cards, the number of ATMs, or the number of EFTPOS terminals) was higher compared with the growth in the value and number of transactions realized by payment cards. Within this group are banking sectors in Belgium, Bulgaria, Finland, Italy, Luxembourg, the Netherlands, Portugal, Romania, Sweden, and Slovenia.

The results of the DEA analysis confirmed the assumption that if an increase in a number of devices is not supported by their usage by clients, it will have the negative impact of the banking sector in the form of efficiency lost. 
The reasons for efficiency change could be also examined by the Malmquist index, which can be dichotomized into its catch-up and frontier-shift components (Palečková, 2017). In Table 1 is evident that the positive efficiency change in most of the analyzed countries was due to catch-up effect, which is evident by the value of catch-up higher than one. This can be seen in the case of Austria, Cyprus, Czech Republic, Germany, Estonia, Spain, France, United Kingdom, Greece, Hungary, Ireland, Lithuania, Latvia, Malta, Poland and Slovakia. It means that in these countries the technical efficiency increased, where the growth rate can be calculated as the difference between the catch-up and one. For instance, in a case of Slovakia, there can be seen technical efficiency increased by $216.74 \%$. In a case of Belgium, Bulgaria, Denmark, Finland, Italy, Luxembourg, Netherlands, Portugal, Romania, Sweden and Slovenia, the value of catch-up effect was lower than one. It means that in these countries the technical efficiency decreased. For instance, in a case of Slovenia, there can be seen the decline in the relative technical efficiency by $9.37 \%$.

Table 1

Super efficiency and decomposition of Malmquist index in the EU countries

\begin{tabular}{|c|c|c|c|c|c|c|c|}
\hline \multirow[b]{2}{*}{ Country } & \multicolumn{2}{|c|}{2005} & \multicolumn{2}{|c|}{2015} & \multirow{2}{*}{$\begin{array}{l}\text { Catch-up } \\
2005-2015\end{array}$} & \multirow{2}{*}{$\begin{array}{c}\text { Frontier-shift } \\
2005-2015\end{array}$} & \multirow{2}{*}{$\begin{array}{c}\text { Malmquist index } \\
2005-2015\end{array}$} \\
\hline & Score & Rank & Score & Rank & & & \\
\hline Austria & 0.2909 & 12 & 1.3391 & 2 & 3.4741 & 0.3180 & 1.1048 \\
\hline Belgium & 1.0044 & 6 & 0.4641 & 13 & 0.4621 & 2.5905 & 1.1972 \\
\hline Bulgaria & 0.0657 & 26 & 0.0521 & 27 & 0.7932 & 0.2585 & 0.2050 \\
\hline Cyprus & 0.2532 & 14 & 1.2569 & 5 & 5.6728 & 0.2213 & 1.2555 \\
\hline Czech Republic & 0.1130 & 25 & 0.2901 & 18 & 2.5685 & 0.3817 & 0.9804 \\
\hline Germany & 0.3962 & 10 & 1.0000 & 10 & 2.6961 & 0.3243 & 0.8743 \\
\hline Denmark & 1.2568 & 4 & 1.3352 & 3 & 0.9341 & 1.1950 & 1.1162 \\
\hline Estonia & 0.2823 & 13 & 0.4830 & 12 & 1.7112 & 1.9201 & 3.2856 \\
\hline Spain & 0.1510 & 19 & 0.1822 & 23 & 1.2071 & 1.4341 & 1.7311 \\
\hline Finland & 1.2879 & 2 & 1.1115 & 8 & 0.8668 & 1.5049 & 1.3044 \\
\hline France & 0.5170 & 8 & 1.1639 & 7 & 2.0614 & 1.2908 & 2.6609 \\
\hline United Kingdom & 1.0601 & 5 & 1.0908 & 9 & 1.0147 & 1.8471 & 1.8743 \\
\hline Greece & 0.0580 & 27 & 0.0605 & 26 & 1.0421 & 1.4380 & 1.4985 \\
\hline Hungary & 0.1375 & 21 & 0.1964 & 22 & 1.4280 & 0.3984 & 0.5690 \\
\hline Ireland & 0.5005 & 9 & 4.0545 & 1 & 2.5159 & 0.6984 & 1.7572 \\
\hline Italy & 0.1816 & 16 & 0.1420 & 24 & 0.7818 & 1.3222 & 1.0337 \\
\hline Lithuania & 0.1601 & 17 & 0.2158 & 21 & 1.3479 & 1.5537 & 2.0942 \\
\hline Luxembourg & 3.2781 & 1 & 1.2547 & 6 & 0.5550 & 0.7097 & 0.3939 \\
\hline Latvia & 0.1585 & 18 & 0.3215 & 17 & 2.0280 & 0.6747 & 1.3683 \\
\hline Malta & 0.1281 & 23 & 0.3530 & 16 & 2.7561 & 0.3394 & 0.9354 \\
\hline Netherlands & 0.6764 & 7 & 0.6247 & 11 & 0.9235 & 1.1639 & 1.0748 \\
\hline Poland & 0.1408 & 20 & 0.2536 & 19 & 1.8008 & 0.3315 & 0.5969 \\
\hline Portugal & 0.3814 & 11 & 0.3541 & 15 & 0.9283 & 2.0480 & 1.9012 \\
\hline Romania & 0.1366 & 22 & 0.0947 & 25 & 0.6934 & 0.3109 & 0.2156 \\
\hline Sweden & 1.2744 & 3 & 1.2587 & 4 & 0.8507 & 1.9316 & 1.6432 \\
\hline Slovenia & 0.2400 & 15 & 0.2176 & 20 & 0.9063 & 1.3882 & 1.2582 \\
\hline Slovakia & 0.1228 & 24 & 0.3890 & 14 & 3.1674 & 0.3907 & 1.2375 \\
\hline
\end{tabular}

Source: Prepared by authors

Another factor which influenced the efficiency score was a frontier-shift effect. In countries like Belgium, Denmark, Estonia, Spain, Finland, France, United Kingdom, Greece, Italy, Lithuania, the 
Netherlands, Portugal, Sweden and Slovenia the value of frontier shift was higher than one, it means that the total productivity factor was affected in positive term. For instance, in a case of Slovenia, there is evident the progress in the frontier technology by $38.82 \%$ A change if the efficiency frontier can be attributable to any change in the environment of mentioned countries. Thus, it captures the effect of technological change as well as the effect of government regulations, central bank policies, overall technological progress, and macroeconomic development and so on. The frontier shift's effect also represents the effect of innovation in evaluated countries. All these issues together with information technology uptake influenced the banks' ability to offer more sophisticated products and services, enabling them to take their products closer to clients and so increase their efficiency.

If the catch-up effect was encouraged by the frontier-shift effect there had the positive impact on total Malmquist index, in form of higher value of total factor productivity. Therefore, the highest Malmquist index can be seen in Estonia, Spain, France, United Kingdom, Greece and Lithuania. The highest value of Malmquist index can be seen in Estonia. It means that this banking sector has taken the most effective decisions, which were also supported by the technological progress. In the Estonian banking sector the increase in the number of issued cards, ATMs and terminals was encouraged by the higher increase in the value and number of transactions realized by payment cards per one employee, which resulted in the growth of efficiency. Although the Estonia was not one of the most efficient countries, the level of improvement was the highest.

If only one effect was positive, then the overall value of the Malmquist index depended on the intensity of both components. Even that one effect was able to prevail over the second one, and it was reflected in the progress of total factor productivity change. If not, the value of the Malmquist index was lower than one indicates deterioration in the total factor productivity. Thus, it may be evident that the usage of payment cards was not encouraged by the technological progress and also of positive changes in the macroeconomic environment of countries, and it did not have to lead to the overall improvement. In case of Germany, it is evident that one of the highest developed countries. The space for technological progress and for significant positive changes in the macroeconomic environment was not as wide as in case of emerging countries. This led to the fact that despite the significant increase in technical efficiency, the overall decline in total factor productivity appeared.

However, there exist also those countries, where both effects are lower than one indicating regress in relative efficiency from period 1 to period 2 and regress in frontier technology. Therefore, the overall Malmquist index was also lower than one. It is evident in the case of Bulgaria, Luxembourg, and Romania. In a case of Bulgaria and Romania the levels of overall improvement were the lowest. As can be seen in these countries a sharp increase in these devices (ATM and EFTPOS) was not encouraged by their use by bank clients. Also overall technological progress and the changes in the macroeconomic environment were not at a sufficient level. All these factors together reflected in regress in total factor productivity.

\section{CONCLUSION}

This paper investigated whether the investment into the implemented technologies - issued payment cards, ATMs and EFTPOS terminals - influenced the efficiency of the banking sectors. Using a sample of 27 European Union countries in 2005 and in 2015, the research primarily focused on whether a wider network of terminals and a higher number of payment cards issued by banks were transformed effectively, and was used by banks' clients in a maximal possible way.

The analysis was done during the period of the rapid development of technologies and also with their usage by banks' clients. It was evident by a significant increase in the number of payment card holders, but also in the number of places where the clients of banks can pay by cards through EFTPOS terminals or 
withdraw cash through ATMs displayed on the figures (Figure 1, Figure 2 and Figure 3). With the fast growth in the number of terminals and cards, the number and the value of payments realized through them also increased as was evident in Figure 4 and Figure 5. The important finding from the research points to the fact that if an increase in the value and number of transactions realized by payment cards exceeded the increase in the number of issued cards, ATMs and terminals, it resulted in the growth of efficiency. However, when the growth of one from the input variables (the number of issued cards, the number of ATMs, or the number of EFTPOS terminals) was higher compared with the growth in the value and number of transactions realized by payment cards, it reflected in the decrease of efficiency.

The results of the analysis point to the fact, that most of the countries reached progress in total factor productivity, which was affected by progress in form of recovery effect, innovation effect, or both of them.

It may be stated that the paper has some limitations. Therefore, for the future research, it could be analyzed how the exclusion of outliers could affect the changes in efficiency. Also, the analyzed period can be divided into sub-periods, e.g. till 2008 and after that date, which can help in assessing the impact of financial crisis

\section{ACKNOWLEDGEMENT}

The research behind this paper was supported by the Slovak Scientific Grant Agency within the project VEGA 1/0446/15.1

\section{REFERENCES}

Adewoye, O.J., \& Omoregie, N.V. (2013). The impact of automatic teller machines on the cost efficiency of Nigeria. Journal of Internet Banking and Commerce, 18(3), 1-20.

Andrieș, A.M., Pleșcău, I., \& Stoica, O. (2016). Macroprudential Policy and Bank Risk in Central and Eastern Europe: The Role of Bank Business Models. Transformations in Business \& Economics, 15(39C), 544-564.

Badawi, Tjahjono, H.K., Muafi. (2017). The role of corporate reputation moderation of banking services. Polish Journal of Management Studies, 15(1), 15-25. doi:10.17512/pjms.2017.15.1.02

Beccalli, E. (2007). Does IT investment improve bank performance? Evidence from Europe. Journal of Banking and Finance, 31(7), 2205-2230. doi:10.1016/j.jbankfin.2006.10.022.

Belás, J., \& Gabčová, L. (2016). The Relationship among Customer Satisfaction, Loyalty and Financial Performance of Commercial Banks. Ekonomie a Management, 19(1), 132-147. doi:10.15240/tul/001/2016-1-010.

Belás, J., Korauš, M., Kombo, F., \& Korauš, A. (2016). Electronic banking security and customer satisfaction and in commercial banks. Journal of Security and Sustainability Issues, 5(3), 411-422. doi:10.9770/jssi.2016.5.3(9).

Bhasin, M. (2016). Challenge of mitigating bank frauds by judicious mix of technology: Experience of a developing country. Economics, Management and Sustainability, 1(1), 23-41. doi:10.14254/jems.2016.1-1.3.

Bod'a, M., \& Zimková, E. (2016). Malmquist index analysis of the recent development of the Slovak banking sector from two different angles. Economic Change and Restructuring, 50(2), 95-131. doi:10.1007/s10644-016-9183-0.

Casu, B., \& Girardone, C. (2006). Bank competition, concentration and efficiency in the single European market. The Manchester School, 74(4), 441-468. doi:10.1111/j.1467-9957.2006.00503.x.

Chochol'áková, A., Gabčová, L., Belás, J. \& Sipko, J. (2015). Bank Customers’ Satisfaction, Customers’ Loyalty and Additional Purchases of Banking Products and Services. A Case Study from the Czech Republic. Economics \& Sociology, 8(3), 82-94. doi:10.14254/2071-789x.2015/8-3/6.

Cooper, W., Seiford, L.M., \& Tone, K. (2007). Data Envelopment Analysis: A comprehensive text with models applications. New York: Springer Science.

Damar, E. H. (2006). The effects of shared ATM networks on the efficiency of Turkish banks. Applied Economics, 38(6), 683697. doi:10.1080/00036840500394264.

Filipovski, B., \& Flood, D. (2010). Reform of the ATM System - One Year On. RBA Bulletin, June, 37-46.

Flood, D., Hancock, J., \& Smith, K. (2011). The ATM Reforms - New Evidence from Survey and Market Data. RBA Bulletin, March, 43-50. 
Floros, Ch., \& Giordani, G. (2008). ATM and banking efficiency: the case of Greece. Banks and Bank Systems, 3(4), $55-65$.

Grigorian, D. A., \& Manole, V. (2006). Determinants of Commercial Bank Performance in Transition: An Application of Data Envelopment Analysis. Comparative Economic Studies, (3), 497-522. doi: 10.1057/palgrave.ces.8100129.

Kheng, Y. K., \& Wooi, H. C. (2011). A DEA analysis on the efficiency of Malaysian commercial banks over 2003-2008. The Institute's Mission Statement, 3.

Korauš, A., Dobrovič, J., Ključnikov, A., \& Gombár, M. (2016). Consumer approach to bank payment card security and fraud. Journal of Security and Sustainability Issues, 6(1), 85-102. doi:10.9770/jssi.2016.6.1(6).

Lazányi, K. (2017). Innovation - the role of trust. Serbian Journal of Management, 12(2), 331-344.

Malmquist, S. (1953). Index Numbers and Indifference Surfaces. Trabajos de Estadistica, 4(2), 209 - 242.

Matutes, C., \& Padilla, A. J. (1994). Shared ATM networks and banking competition. European Economic Review, 38(5), $1113-$ 1138.

Michalski, G. (2014). Value-Based Working Capital Management. 2014, Palgrave Macmillan, 181 p. doi:10.1057/9781137391834.

Michalski, G. (2016). Risk Pressure and Inventories Levels. Influence of Risk Sensitivity on Working Capital Levels. Economic Computation and Economic Cybernetics Studies and Research, Editura Academia de studii economice, 50(1), 189-196.

Mikalauskiene, A., Mulagalejeva, K., \& Štreimikiene, D. (2016). Assess the Impact of Globalisation Processes by Indices. Economics and Sociology, 9(4), 82-100. doi:10.14254/2071-789X.2016/9-4/5

Miklaszewska, E., \& Kil, K. (2016). The impact of 2007-2009 crisis on the assessment of bank performance: The evidence from CEE-11 countries. Transformation in Business \& Economics, 15(2A), 459-479.

Naiwen L., Xu J.X., \& Ahmad, M.I. (2018). Banking performance of China and Pakistan. Entrepreneurship and Sustainability Issues, 5(4). doi:10.9770/jesi.2018.5.4(16)

Nuhiu, A., Hoti, A., \& Bektashi, M. (2017). Determinants of commercial banks profitability through analysis of financial performance indicators: evidence from Kosovo. Business: Theory and Practice, 18, 160-170.

Ou, C. S., Hung, S. Y., Yen, D. C., \& Liu, F. C. (2009). Impact of ATM intensity on cost efficiency: An empirical evaluation in Taiwan. Information \& Management, 46(8), 442-447. doi:10.1016/j.im.2009.08.005.

Palečková, I. (2017). Efficiency change of banking sectors and banks in the financial conglomerates in Visegrad group countries. Ekonomický časopis (Journal of Economics), 65(1), 79-92.

Prager, R. A. (1999). ATM network mergers and the creation of market power. Antitrust Bulletin, 44(2), 349-363.

Puriwat, W., \& Tripopsakul, S. (2017). The impact of e-service quality on customer satisfaction and loyalty in mobile banking usage: case study of Thailand. Polish Journal of Management Studies, 15(2), 183-193. doi:10.17512/pjms.2017.15.2.17

Salonder, G., \& Shepard, A. (1995). Adoption of technologies with network effects: an empirical examination of the adoption of Automated Teller Machine. RAND Journal of Economics, 26(3), 479-501.

Sinicakova, M., Sulikova, V., \& Gavurova, B. (2017). Twin Deficits Threat in the European Union. E+M Ekonomie a Management, 20(1), 144-156. doi:10.15240/tul/001/2017-1-010.

Svitálková, Z. (2014). Comparison and Evaluation of Bank Efficiency in Austria and the Czech Republic. Journal of Competitiveness, 6(2), 15-29. doi: 10.7441/joc.2014.02.02.

Szczygieł N., Rutkowska-Podolska M., \& Michalski G. (2015) Information and Communication Technologies in Healthcare: Still Innovation or Reality? Innovative and Entrepreneurial Value - creating Approach in Healthcare Management. In 5th Central European Conference in Regional Science Conference Proceedings / Nijkamp Pater [i in.] (eds.), 2015, Technical University of Košice, 1020-1029.

Tregenna, F. (2009). The Fat Years: The Structure and Profitability of the US Banking Sector in the Pre-crisis Period. Cambridge Journal of Economics, (4), 609-632. doi:10.1093/cje/bep025.

Yang, C. C. (2017). Reduction of non-performing loans in the banking industry: an application of data envelopment analysis. Journal of Business Economics and Management, 18(5), 833-851. doi:10.3846/16111699.2017.1358209

Zimková, E. (2015). Technical efficiency and super-efficiency of the insurance sector in Slovakia. Acta Universitatis Agriculturae et Silviculturae Mendelianae Brunesis, 63(6), 2205-2211. doi:10.11118/actaun201563062205.

Zuzeviciute, V., Praneviciene, B., Simanaviciene, Z., \& Vasiliauskiene, V. (2017). Competence for Sustainability-Prevention of Dis-Balance in Higher Education: The Case of Cooperation While Educating Future Law Enforcement Officers. Montenegrin Journal of Economics, 13(4), 121-130. doi:10.3846/btp.2017.017. 